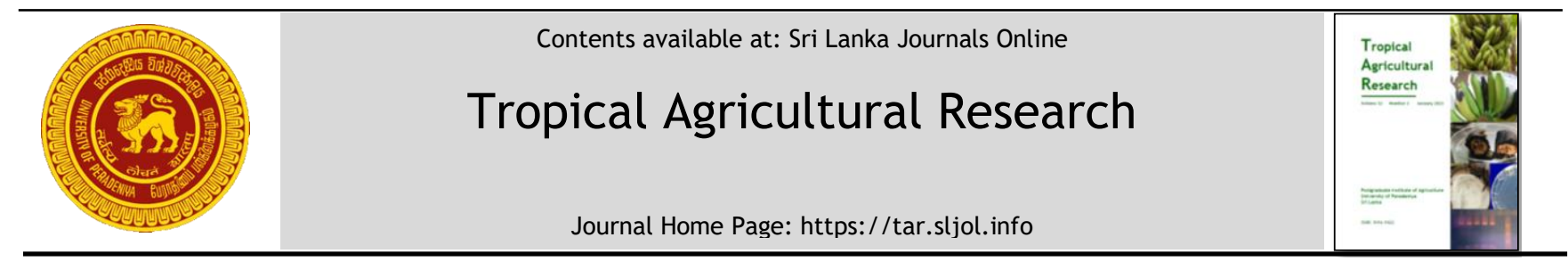

\title{
Vegetable Crops Prefer Different Ratios of Ammonium-N and Nitrate-N in the Growth Media
}

\author{
K.K.K. Nawarathna ${ }^{1,2}$, W.S. Dandeniya ${ }^{3}{ }^{*}$, R.S. Dharmakeerthi ${ }^{3}$ and P. Weerasinghe ${ }^{4}$ \\ ${ }^{1}$ Postgraduate Institute of Agriculture, University of Peradeniya, Peradeniya, Sri Lanka. \\ ${ }^{2}$ Horticultural Crops Research and Development Institute, Gannoruwa, Peradeniya, Sri Lanka. \\ ${ }^{3}$ Department of Soil Science, Faculty of Agriculture, University of Peradeniya, Peradeniya, Sri Lanka. \\ ${ }^{4}$ Climate Resilience and Irrigated Agriculture Project, Ministry of Agriculture, 288 DPJ Tower, Sir Jayawardanapura \\ Mawatha, Rajagiriya, Sri Lanka.
}

\section{ARTICLE INFO}

\section{Article history:}

Received: 20 July 2020

Revised version received: 10 October 2020

Accepted: 05 November 2020

Available online: 1 January 2021

\section{Keywords:}

Ammonium-N

Nitrate-N

Nitrogen form

Sand culture

Nutrient uptake

\section{Citation:}

Nawarathna, K.K.K., Dandeniya, W.S., Dharmakeerthi, R.S., and Weerasinghe, P. (2021). Vegetable Crops Prefer Different Ratios of Ammonium-N and Nitrate- $\mathrm{N}$ in the Growth Media. Tropical Agricultural Research, 32(1): 95-104.

DOI: http://doi.org/10.4038/tar.v32i1.8445

Nawarathna, K.K.K

https://orcid.org/0000-0002-8939-4397

\section{ABSTRACT}

Understanding the preference of a crop for forms of nitrogen (N) is important to ensure efficient use of $\mathrm{N}$-sources in agriculture. A study was conducted to assess nutrient uptake and dry matter yield of six vegetable crops under different ratios of ammonium$\mathrm{N}\left(\mathrm{NH}_{4}{ }^{+}-\mathrm{N}\right)$ and nitrate-N $\left(\mathrm{NO}_{3}{ }^{-}-\mathrm{N}\right)$ in growth medium. Seedlings of cabbage, carrot, capsicum, knolkhol, lettuce, and tomato, were supplied with five $\mathrm{N}$-treatments $\left(\mathrm{NH}_{4}{ }^{+}-\mathrm{N}: \mathrm{NO}_{3}{ }^{-}-\mathrm{N}\right.$ in the ratios of $0: 100,25: 75,50: 50,75: 25$ and 100:0) under controlled environment in sand culture. Six weeks after initiating treatments plants were harvested and dry matter recorded. Plants were analysed for total N, P and K contents. Dry-matter yield, $\mathrm{N}$ and $\mathrm{K}$ concentrations in shoot-tissues in response to $\mathrm{N}$ treatments were significantly different $(\mathrm{p}<0.05)$ among crops. Tomato and knolkhol showed high dry matter yield and $\mathrm{N}$ content when supplied with $\mathrm{NO}_{3}-\mathrm{N}$ than $\mathrm{NH}_{4}{ }^{-}-\mathrm{N}$. The highest dry matter yield for cabbage was obtained with equal supply of NO3$-\mathrm{N}$ and $\mathrm{NH}_{4}{ }^{+}-\mathrm{N}$ than supplying either form alone. Dry matter yield and $\mathrm{N}$ concentration in shoots of lettuce, capsicum and carrot were not significantly affected $(p>0.05)$ by N-treatment. Supplying $\mathrm{NH}_{4}^{+}-\mathrm{N}$ alone significantly reduced $\mathrm{K}$ concentration in shoot tissues in knolkhol, capsicum and tomato. This study revealed that performance of vegetable crops is affected by the $\mathrm{NH}_{4}{ }^{+}-\mathrm{N}$ : $\mathrm{NO}_{3}-\mathrm{N}$ in the growth medium. This knowledge can be utilized to optimize fertilizer-N usage in vegetable cultivation.

*Corresponding author : warshisd@pdn.ac.lk 


\section{INTRODUCTION}

Ammonium $\left(\mathrm{NH}_{4}^{+}\right)$and nitrate $\left(\mathrm{NO}_{3}^{-}\right)$are the plant available $\mathrm{N}$ forms in soil. Under aerobic soil condition (unsaturated soil) $\mathrm{NH}_{4}{ }^{+}$is readily converted to $\mathrm{NO}_{3}$ - via a microbiologically mediated nitrification process. Nitrate is the predominant plant available $\mathrm{N}$ form under unsaturated soil conditions, which account for more than $80 \%$ of available N pool (Sylvia et al., 2005). Nitrate is an anion present mostly in soil solution and has a high potential to leach out from soil or to be lost through denitrification becoming unavailable for plant uptake (Sylvia et al., 2005). Application of $\mathrm{N}$ fertilizers along with nitrification inhibitors, split application of $\mathrm{N}$ fertilizers and the use of slowrelease $\mathrm{N}$ fertilizers have been practiced to retard $\mathrm{NO}_{3}{ }^{-}$releasing rate to soil solution and these practices have improved $\mathrm{N}$ use efficiency and crop productivity under field conditions (Slangen and Kerkhoff, 1984; Rodgers, 1986; Upadhya et al., 2011; Kemal and Workie, 2015; Herrera et al., 2016). However, the nitrogen use efficiency, quality of harvest and crop productivity have been found to depend on $\mathrm{NH}_{4}{ }^{+}-\mathrm{N}: \mathrm{NO}_{3}-\mathrm{N}$ ratio (Serna et al., 1992; Palaniswamy et al., 2002; Heebe, 2005; Omari and Nihri, 2015) and the optimum ratio appears to be crop specific (Kafkafi, 2009).

A study conducted with different ratios of $\mathrm{NH}_{4}{ }^{+-}$ $\mathrm{N}: \mathrm{NO}_{3}-\mathrm{N}$ on canola under salt stress condition revealed that supplying $\mathrm{N}$ with 50:50 ratio of $\mathrm{NH}_{4}^{+}-$ $\mathrm{N}$ : $\mathrm{NO}_{3}-\mathrm{N}$ protected plants from salinity stress

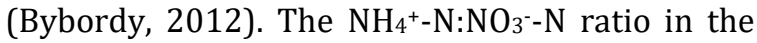
growth medium is known to affect qualitative aspects of the crop. Supplying most of the $\mathrm{N}$ in the form of $\mathrm{NH}_{4}{ }^{+}$improved sweetness, taste and flavours of tomato (Heeb, 2005), reduced oxalic acid content in purslane leaves (Palaniswamy et al., 2002), and improved fatty acid content in canola (Bybordy 2012). Serna et al. (1992) showed that when $\mathrm{NH}_{4}{ }^{+}$proportion in the $\mathrm{N}$ supply was increased, phosphorus, magnesium, ferrous and copper contents of leaves increased while calcium, potassium, manganese and zinc contents decreased. Sensitivity of crop to the $\mathrm{NH}_{4}{ }^{+}-\mathrm{N}: \mathrm{NO}_{3}-\mathrm{N}$ ratio is an important factor to consider when deciding the degree of nitrification inhibition required and the type of $\mathrm{N}$ fertilizer to be applied for optimizing $\mathrm{N}$ fertilizer use efficiency. By knowing the plant preferences for $\mathrm{NH}_{4}{ }^{+}-\mathrm{N}$ and $\mathrm{NO}_{3}{ }^{-}$ $-\mathrm{N}$, it would be possible to develop better nutrient management practices to improve nutrient use efficiency of crops. Therefore, this study was conducted with the objective of assessing the effect of the form of $\mathrm{N}$ on dry matter yield and nutrient uptake of six popular vegetable crops in Sri Lanka. This was achieved by using cabbage, carrot, capsicum, knolkhol, lettuce and tomato as target crops grown at different $\mathrm{NH}_{4}{ }^{-}-\mathrm{N}$ : $\mathrm{NO}_{3}-\mathrm{N}$ ratios in a controlled environment.

\section{METHODOLOGY}

When selecting vegetable crops for the study, information was gathered for popular vegetable crops in relation to demand for $\mathrm{N}$ (Lathif and Yapa, 2010), N removal with harvest (unpublished data), the land extent under cultivation (Statistics of Ministry of Agriculture, 2016) and suitability of the crop to grow at Gannoruwa, Sri Lanka (WM2b agro-ecological zone). Accordingly, cabbage, carrot, capsicum, knolkhol, lettuce and tomato were selected and the varieties used for the study were F1 Hybrid AS39, Kuroda, CA8, Early White Vianna, Grand Rapid and T 246, respectively. Daily mean temperature during experimentation period was $29 \pm 2^{\circ} \mathrm{C}$.

\section{Preparing planting materials and establishing pot experiment}

Acid washed and sterilized sand was used for establishing nurseries and as the anchoring medium for the pot experiment in greenhouse. Nurseries were established for cabbage, capsicum, knolkhol, lettuce and tomato in sand beds prepared in trays. In preparing planting materials, seedlings were grown supplying nutrients using quarter strength Albert's solution ${ }^{\circledR}$, a commercial liquid fertilizer mixture (Unipower (PVT.) Ltd. USA) which included ammonium-N (0.2\%) and nitrate$\mathrm{N}(10.3 \%)$ as the $\mathrm{N}$ sources. At the end of the nursery period uniformly grown and vigorous seedlings were uprooted, the roots were immersed in Captan ${ }^{\circledR}$ (commercially available fungicide) and transplanted in the pots. The double pot method was used for the pot experiment. A $500 \mathrm{ml}$ pot, which was perforated on sides and the bottom served as the planting compartment and placed in a pot with a larger diameter, which served as the nutrient reservoir. The planting compartment was filled with $500 \mathrm{~g}$ of $2 \mathrm{~mm}$ sieved, acid washed and sterilized sand. The liquid fertilizer mixture was applied to the nutrient reservoir and the perforated walls facilitated free nutrient movement into planting compartment. Two selected seedlings from nurseries were transplanted per pot in sand filled planting compartment. For each crop 25 pots were prepared. For all crops, except carrot, $500 \mathrm{ml}$ of half strength Albert's solution ${ }^{\circledR}$ was applied per pot for one-week period until plants got stabilized in the pots. Then plants were thinned out leaving one plant per pot and $\mathrm{N}$ treatments were imposed. Unlike other crops, carrot was not transplanted. Hence, carrot was direct seeded in the sand filled planting compartment of each pot at the rate of 10 
seeds / pot at the time of establishing nurseries for other crops. Then pots containing carrot seeds were initially supplied with quarter strength Albert's solution ${ }^{\circledR}$ for two weeks followed by half strength Albert's solution ${ }^{\circledR}$ for 4 weeks. At this stage, carrot seedlings were thinned out leaving one healthy, uniform seedling per pot and the $\mathrm{N}$ treatment was commenced in parallel to other crops.

\section{$\mathbf{N}$ treatment}

Hoagland fertilizer solution (Hoagland and Arnon, 1950) was used as the basis for preparing liquid fertilizer medium. The composition of the Hoagland solution was $200 \mathrm{ppm}$ of N, $235 \mathrm{ppm}$ of $\mathrm{K}, 200 \mathrm{ppm}$ of $\mathrm{Ca}, 31 \mathrm{ppm}$ of $\mathrm{P}, 64 \mathrm{ppm}$ of $\mathrm{S}, 48 \mathrm{ppm}$ of $\mathrm{Mg}, 0.5 \mathrm{ppm}$ of $\mathrm{B}, 1.0 \mathrm{ppm}$ of Fe, $0.5 \mathrm{ppm}$ of $\mathrm{Mn}$, $0.005 \mathrm{ppm}$ of $\mathrm{Zn}, 0.02 \mathrm{ppm}$ of $\mathrm{Cu}$, and $0.01 \mathrm{ppm}$ of Mo. Five $\mathrm{N}$ treatments were developed to supply 200 ppm of $\mathrm{N}$ either using $\mathrm{NH}_{4}^{+}-\mathrm{N}$ or $\mathrm{NO}_{3}-\mathrm{N}$ as the sole form, or as mixtures of both $\mathrm{NH}_{4}^{+}$and $\mathrm{NO}_{3}-$ in different proportions, while keeping all other nutrients at constant levels. The five $\mathrm{N}$ treatments corresponding to the percentage of each form to supply $200 \mathrm{ppm}$ of $\mathrm{N}$ when presented as a ratio of $\mathrm{NH}_{4}{ }^{+}: \mathrm{NO}_{3}{ }^{-}$were $\mathrm{N}_{0: 100}, \mathrm{~N}_{25: 75}, \mathrm{~N}_{50: 50}, \mathrm{~N}_{75: 25}$ and $\mathrm{N}_{100: 0}$. Potassium nitrate, ammonium hydroxide and ammonium nitrate of analytical reagent (AR) grade were used to prepare the $\mathrm{N}$-treatments. All five fertilizer mixtures were supplemented with dicyandiamide (DCD), a synthetic nitrification inhibitor, at a rate of $10 \mathrm{mg} / \mathrm{kg}$ of sand culture to ensure that the plants experienced the intended $\mathrm{NH}_{4}^{+}: \mathrm{NO}_{3}{ }^{-}$ratio in each treatment. The $\mathrm{pH}$ of the liquid fertilizer medium was adjusted between 6.5 to 7.0 using diluted sodium hydroxide and hydrochloric acid. Nutrient solution compartment of each pot was filled with $500 \mathrm{ml}$ of Hoagland solution with respective $\mathrm{N}$ treatment and this was renewed twice a week to supply the plants with intended $\mathrm{NH}_{4}{ }^{+}: \mathrm{NO}_{3}{ }^{-}$levels for a period of 6 weeks for every crop. The solution level was topped-up regularly with distilled water to make it $500 \mathrm{ml}$ until the next turn of re-fill. The N-treatment was applied in five replicates per crop and pots were arranged in a complete randomized design (CRD) in the greenhouse. Pots were randomly rearranged once a week to avoid environmental variables in the greenhouse.

\section{Crop harvesting, data collection and plant sample analysis}

Crops were harvested after the vegetative phase. Shoots and roots were carefully harvested and gently washed with tap water to remove soil and dust particles. Then they were dipped in distilled water, drained and extra moisture was removed using paper towels. Shoots and roots were separated from all crops except for lettuce, in which whole plant was used for the analysis. The samples were oven dried at $60{ }^{\circ} \mathrm{C}$ until a constant weight and brittle texture was gained. Finally, dry weights of all plant samples were measured. Dried samples were ground to a fine powder using a mortar and a pestle, labelled and stored for further analysis in sealed polythene bags. Before nutrient analysis, all plant samples of cabbage were destroyed due to a malfunctioning of the thermal control of the oven. Hence, only the shoot dry weight of cabbage crop is reported herein.

Shoot and root samples were analysed separately for total $\mathrm{N}$ for knolkhol, carrot, capsicum, and tomato and as the whole plant for lettuce after wet acid digestion following Kjeldahl method (Jackson, 1958). Remaining plant samples were digested with nitric acid (Jackson, 1958; Huang, 2004) and the extract was used to determine $P$ colourimetrically (Olsen and Sommers, 1982) at $470 \mathrm{~nm}$ absorption using a spectrophotometer (Jenway 6305 UV/VIS Spectrometer), and K following the method described by Baruah and Barthakur (1997) using flame photometer (BWB Technologies-Flame photometer). Parameters related to nutrient concentrations, uptake and recovery for $\mathrm{N}, \mathrm{P}$ and $\mathrm{K}$ were calculated using following equations (equations 1 to 5).

Nutrient concentrations $(\mathrm{X})=$ mass of nutrient per unit dry matter $(\mathrm{mg} / \mathrm{kg})$ equation 1

Nutrient content in shoots $(\mathrm{Y})=$

$\mathrm{X} \times$ shoot dry matter of a plant (mg/plant) equation 2

Nutrient content in roots (Z) $=\mathrm{X} \times$ root dry matter of a plant equation 3

Total nutrient uptake $(\mathrm{mg} /$ plant $)=\mathrm{Y}+\mathrm{Z}$ equation 4

Nutrient recovery $=$ (Total nutrient uptake/ total nutrient added to plant) $\times 100$

equation 5

\section{Statistical analysis}

A two factor factorial design with generalized linear model (GLM) procedure was used in conducting analysis of variance (ANOVA) to assess the significance of the effect of $\mathrm{N}$ form/s in the growth medium ( $\mathrm{N}$ treatment) on dry matter yield and nutrient uptake of crops. Crop and $\mathrm{N}$ treatment were used as the two groups in factorial analysis. When the main effect or the interaction effect was 
significant the mean comparison was performed with Tukey mean separation technique. The correlations between different parameters were assessed using Pearson's correlation test at $p<0.05$. Statistical analyses were performed with Minitab 17 Statistical Software (2010) [State College, PA: Minitab, Inc. (www.minitab.com)].

\section{RESULTS AND DISCUSSION}

Plants assimilate nitrogen in the forms of $\mathrm{NH}_{4}{ }^{+}$ and/or $\mathrm{NO}_{3}$. The dry matter yield of roots and shoots, nutrient accumulation and tissue nutrient concentration in studied crops were significantly affected by the $\mathrm{NH}_{4}{ }^{+}-\mathrm{N}: \mathrm{NO}_{3}-\mathrm{N}$ ratio in the growth medium (Table 1). Changes in dry matter yield and uptake of $\mathrm{N}$ and $\mathrm{K}$ with the ratio of $\mathrm{NH}_{4}{ }^{+}-\mathrm{N}: \mathrm{NO}_{3}{ }^{-} \mathrm{N}$ in the growth medium has been reported previously for vegetable crops (Ikeda and Osawa, 1981; Marti and Mills, 1991; Song et al., 2000; Tian et al, 2003; Zhang et al., 2010; Nasraoui et al., 2011). According to previous studies, preference of a crop for $\mathrm{NH}_{4}{ }^{+}$and $\mathrm{NO}_{3}$ - could change with crop growth stage (Ganmore-Neumann and Kafkari, 1985; Marti and Mills, 1991; Cui et al., 2017). It should be noted that in this study all crops reached the end of vegetative period. In lettuce, the crop is considered matured and harvested at the end of vegetative phase. Performance of a crop during vegetative stage is important for its performance at reproductive stage.

\section{Dry matter yield}

The effect of $\mathrm{N}$ treatment on dry matter yield was not consistent among the studied crops at the end of the six-week period as indicated by the significant interaction effect between $\mathrm{N}$-treatment and crop type (Table 1 and Figure 1). Total dry matter yield of lettuce and carrot during vegetative stage were not significantly affected by $\mathrm{NH}_{4}{ }^{+}-$ $\mathrm{N}: \mathrm{NO}_{3}-\mathrm{N}$ in the growth medium. Scaife et al. (1986) showed that lettuce can be grown satisfactorily at very low $\mathrm{NO}_{3}-\mathrm{N}$ content while supplying ammonium sulphate and inhibiting nitrification. In the same study, they stated that tip burn was less serious with plants grown with $\mathrm{NH}_{4}^{+}-\mathrm{N}$ nutrition than those with $\mathrm{NO}_{3}-\mathrm{N}$. However, Tian et al. (2003) reported that $\mathrm{NO}_{3}-\mathrm{N}$ is the most suitable form of $\mathrm{N}$ for lettuce. Differences in growth conditions, especially the temperature and growth duration and varietal differences may have contributed to contrasting observations related to lettuce (Ganmore-Neumann and Kafkafi, 1985; Song et al., 2011; Cui et al, 2017). Ganmore-Neumann and Kafkafi (1985) observed that preferential uptake of $\mathrm{NH}_{4}{ }^{+}-\mathrm{N}$ and $\mathrm{NO}_{3}-\mathrm{N}$ change with root temperature in addition to the crop growth stage. In the present study, dry matter yield of knolkhol and tomato were high under high $\mathrm{NO}_{3}^{--} \mathrm{N}\left(\mathrm{NH}_{4}^{+}-\mathrm{N}: \mathrm{NO}_{3}^{--} \mathrm{N}\right.$, $0: 100)$ in the growth medium, whereas cabbage had the highest dry matter yield at 50:50, $\mathrm{NH}_{4}{ }^{+}-\mathrm{N}$ to $\mathrm{NO}_{3}-\mathrm{N}$ ratio. Nasraoui et al., (2011) observed that tomato plants preferred $\mathrm{NO}_{3}^{-}$while $\mathrm{NH}_{4}{ }^{+}$ inhibited its growth. Song et al, (2001) reported that supplying $\mathrm{N}$ with $25 \% \mathrm{NH}_{4}{ }^{+}$in a nutrient solution increased plant height, stem diameter and dry matter of Chinese cabbage (Brassica rapa) when compared to supplying $\mathrm{NO}_{3}{ }^{-}$as the primary $\mathrm{N}$ source $\left(100 \% \mathrm{NO}_{3}^{-}-\mathrm{N}\right)$. Present study used a different cabbage species (Brassica oleracea capitata) and therefore, this suggests that there can be differences among crop species on how they respond to $\mathrm{NH}_{4}{ }^{+}-\mathrm{N}: \mathrm{NO}_{3}-\mathrm{N}$ in the growth medium. In the present study, although the treatment effect was not significant $(p>0.05)$ the dry matter yield of capsicum grown under $50 \%$ and $75 \% \mathrm{NH}_{4}{ }^{-}-\mathrm{N}$ in the growth medium resulted in numerically higher dry matter yield than other treatments (Figure 1).

\section{Nitrogen nutrition of plant}

Nitrogen nutrition of different crops varied with $\mathrm{NH}_{4}^{+}-\mathrm{N}: \mathrm{NO}_{3}-\mathrm{N}$ ratio in the growth medium. Tissue $\mathrm{N}$ concentration was significantly affected by crop type, N-treatment and their interaction while $\mathrm{N}$ content in shoot and total $\mathrm{N}$ uptake were significantly affected only by $\mathrm{N}$-treatment and interaction effect (crop type and N-treatment) (Table 1). Nutrient accumulation is governed by two main factors that are growth status or dry matter yield and nutrient availability (DevinneBarret et al., 2000). In the present study, the treatment effects on nutrient uptake by crops were further analysed by considering the nutrient accumulation in shoot. Nitrogen content in shoots of carrot, lettuce and knolkhol were not significantly affected by $\mathrm{NH}_{4}{ }^{+}-\mathrm{N}: \mathrm{NO}_{3}-\mathrm{N}$ ratio (Table 2). Tomato and capsicum showed variation in shoot $\mathrm{N}$ content according to $\mathrm{NH}_{4}{ }^{+}-\mathrm{N}: \mathrm{NO}_{3}-\mathrm{N}$ ratio in the growth medium (Table 2). The concentration of $\mathrm{N}$ in shoot was affected only in tomato in which the highest concentration was achieved with 50:50 of $\mathrm{NH}_{4}{ }^{+}-\mathrm{N}: \mathrm{NO}_{3}{ }^{-}-\mathrm{N}$ ratio (Figure 2 a.).

However, shoot $\mathrm{N}$ content in tomato was highest under 0:100 of $\mathrm{NH}_{4}^{+}-\mathrm{N}: \mathrm{NO}_{3}{ }^{-} \mathrm{N}$ ratio and it was lowest under 100:0 of $\mathrm{NH}_{4}^{+}-\mathrm{N}: \mathrm{NO}_{3}-\mathrm{N}$ ratio when compared to other treatments (Table 2). The highest $\mathrm{N}$ content in capsicum shoots was observed in 100:0, $\mathrm{NH}_{4}^{+}-\mathrm{N}: \mathrm{NO}_{3}-\mathrm{N}$ ratio (Table 2). Ikeda and Osawa (1981) showed that the preference between $\mathrm{NH}_{4}{ }^{+}-\mathrm{N}$ and $\mathrm{NO}_{3}-\mathrm{N}$ in $\mathrm{N}$ absorption was different among vegetables in a study conducted with 20 different vegetables. In their study, lettuce assimilated more $\mathrm{N}$ in the form of $\mathrm{NH}_{4}{ }^{+}$while cabbage and tomato assimilated $\mathrm{NO}_{3}^{-}$more dominantly. 
Table 1: Analysis of variance of the effects of crop type, nitrogen form and their interaction on dry matter yield, nitrogen, phosphorus and potassium nutrition of the six crops considered.

\begin{tabular}{lccc}
\hline \multicolumn{4}{c}{ Dry matter yield } \\
\hline Effect & Shoot dry weight & Root dry weight & Total dry weight \\
\hline Crop & $* * *$ & $* * *$ & $* * *$ \\
N-treatment & $* * *$ & $* * *$ & $* * *$ \\
Crop $\times$ N-treatment & $* * *$ & $* * *$ & $* * *$ \\
CV\% & 97.2 & 93.9 & 75.4 \\
$\mathrm{R}^{2}(\%)$ & 85.2 & 68.2 & 83.4 \\
\hline \multicolumn{4}{c}{ N nutrition } \\
\hline Effect & Tissue N Concentration & N content in shoot & Total N Uptake \\
\hline Crop & $* * *$ & $* * *$ & $* * *$ \\
N-treatment & $* * *$ & $* * *$ & $* * *$ \\
Crop $\times \mathrm{N}$-treatment & $* * *$ & $* * *$ & $* * *$ \\
CV\% & 23.4 & 97.8 & 73.1 \\
$\mathrm{R}^{2}(\%)$ & 80.9 & 88.4 & 80.9 \\
\hline
\end{tabular}

\begin{tabular}{lccc}
\hline \multicolumn{4}{c}{ P nutrition } \\
\hline Effect & Tissue P Concentration & P content in shoot & Total P Uptake \\
\hline Crop & $* * *$ & $* * *$ & $* *$ \\
N-treatment & $* * *$ & Ns & Ns \\
Crop $\times$ N-treatment & $* * *$ & $*$ & Ns \\
CV\% & 79.9 & 100.8 & 178.0 \\
$\mathrm{R}^{2}(\%)$ & 73.6 & 53.3 & 38.1 \\
\hline \multicolumn{5}{c}{ K nutrition } \\
\hline Effect & Tissue K Concentration & K content in shoot & Total K Uptake \\
\hline Crop & $* * *$ & Ns & $*$ \\
N-treatment & $* * *$ & Ns & Ns \\
Crop $\times$ N-treatment & $* * *$ & Ns & Ns \\
CV $\%$ & 27.4 & 70.4 & 65.3 \\
$\mathrm{R}^{2}(\%)$ & 91.5 & 63.55 & 46.4 \\
\hline
\end{tabular}

The effects followed by $* * *$, and $* * *$ are significant at $\mathrm{p}$ value $<0.05,<0.01$ and $<0.001$, respectively. Ns=Not significant $(\mathrm{p}>0.05) . \mathrm{R}^{2}$ indicates goodness of fit of model.

A study by Heeb (2005) suggested that $\mathrm{NH}_{4}{ }^{+}-\mathrm{N}$ as an equivalent $\mathrm{N}$ source for tomato compared to $\mathrm{NO}_{3}^{-}-\mathrm{N}$ and $\mathrm{NH}_{4}^{+}-\mathrm{N}$ improved sweetness, acidity and flavour of tomato. A study conducted by Scaife et al. (1986) indicated that lettuce absorb more $\mathrm{N}$ in the presence of high concentration of $\mathrm{NH}_{4}^{+}-\mathrm{N}$.
Similar observations have been made with rice varieties and strawberry indicating presence of $\mathrm{NH}_{4}{ }^{+}-\mathrm{N}$ in the growth medium promoting $\mathrm{NO}_{3}^{-}-\mathrm{N}$ uptake by plant (Ganmore-Neumann and Kafkafi, 1985; Kronzucker et al., 1999). 


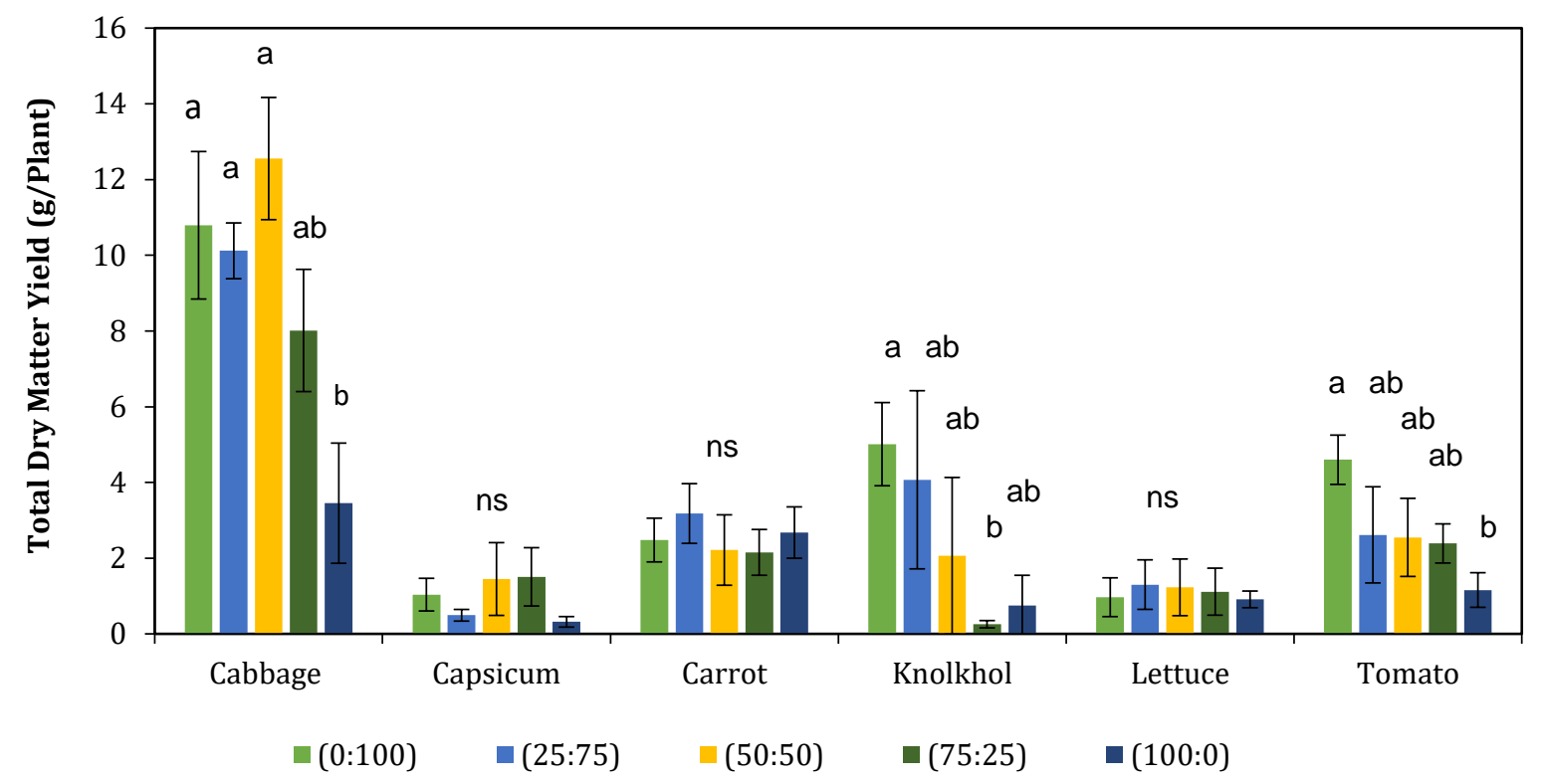

Figure 1: Total dry matter yield in different vegetable crops at the end of vegetative stage as affected by different $\mathrm{NH}_{4}{ }^{+}-\mathrm{N}: \mathrm{NO}_{3}-\mathrm{N}$ ratio in supplying $\mathrm{N}$ in the growth medium. Error bars represent standard deviation $(n=5, p<0.05)$. When the treatment effect is not significant $(p>0.05)$ on dry matter yield of a crop, it is denoted as ' $n s$ '.

\section{Phosphorus and potassium contents in tissue}

$\mathrm{N}$ treatment, crop type and their interactions differently affected contents and concentrations of $\mathrm{P}$ and $\mathrm{K}$ in shoots (Table 1). Significant effect of $\mathrm{N}$ treatments on shoot $\mathrm{P}$ content was observed for tomato and carrot crops only (Table 2 and Figure 2b.). Total K uptake was significantly affected by crop type only (Table 1 ). Tissue $\mathrm{K}$ concentration and $\mathrm{K}$ content in shoot tend to be higher when plants were supplied with $\mathrm{NO}_{3}{ }^{-}$in the growth medium for knolkhol and tomato (Figure 2c and Table 2). Antagonistic interaction between $\mathrm{K}^{+}$and $\mathrm{NH}_{4}{ }^{+}-\mathrm{N}$ during crop nutrient uptake is well established (Marti and Mills, 1991; Zhang et al., 2010). However, $\mathrm{K}$ accumulation in shoots of capsicum (Table 2) and tissue $\mathrm{K}$ concentration of carrot (Figure 2c) indicated that there may be exceptions for the interaction between $\mathrm{K}^{+}$and $\mathrm{NH}_{4}{ }^{+}-\mathrm{N}$ in nutrient uptake of crops during vegetative growth. Ammonium- $\mathrm{N}$ inhibit the activity of high affinity $\mathrm{K}^{+}$transport system but not the low affinity $\mathrm{K}^{+}$transport system in plant roots during $\mathrm{K}^{+}$uptake. Looking into partitioning of $\mathrm{N}, \mathrm{P}$ and $\mathrm{K}$ into shoots and roots with different $\mathrm{N}$ treatments should be done to arrive at valid conclusions. More $\mathrm{K}^{+}$translocation to leaves under $\mathrm{NH}_{4}{ }^{+}-\mathrm{N}$ nutrition compared to that under $\mathrm{NO}_{3}{ }^{-} \mathrm{N}$ nutrition has been observed previously (Zhang et al., 2010). Due to limitation of sample weights $\mathrm{K}$ and $\mathrm{P}$ analyses could not be performed for root samples in the present study.

In general, the nutrient recovery in this study remained less than $28 \%$ with average recovery of $\mathrm{N}, \mathrm{P}$ and $\mathrm{K}$ amounting to $5 \%, 8 \%$ and $5 \%$ respectively. There was no significant effect of crop type, $\mathrm{N}$-treatment or their interaction on nutrient recovery $(p>0.05)$. The nutrient recovery values suggest that nutrient supply was not limited for crop throughout the duration of the pot experiment. Therefore, the observed effects could be attributed to the effect of crop type, $\mathrm{N}$-treatment (form/s of $\mathrm{N}$ supplied) and their interaction effect. 
Table 2: Nitrogen, phosphorus and potassium content in shoot with different nitrogen treatments

\begin{tabular}{|c|c|c|c|c|c|}
\hline \multirow[b]{2}{*}{$\mathrm{NH}_{4}^{+}: \mathrm{NO}_{3}^{-}$} & \multicolumn{5}{|c|}{$\mathrm{N}$ content in shoot (mg/plant) } \\
\hline & Lettuce* & Tomato & Carrot & Capsicum & Knolkhol \\
\hline $0: 100$ & $29.9^{a}$ & $167.6^{\mathrm{a}}$ & $36.1^{\mathrm{a}}$ & $26.8^{\mathrm{ab}}$ & 124.9 a \\
\hline $25: 75$ & $53.1^{\mathrm{a}}$ & $80.0^{b}$ & $42.7^{\mathrm{a}}$ & $38.4 \mathrm{ab}$ & $150.2^{\mathrm{a}}$ \\
\hline $50: 50$ & $48.7^{\text {a }}$ & $101.6^{b}$ & $30.4^{\mathrm{a}}$ & $13.3^{b}$ & $44.8^{a}$ \\
\hline $75: 25$ & $49.8^{a}$ & $73.1^{b}$ & $32.7^{\mathrm{a}}$ & $15.9^{b}$ & $45.1^{\mathrm{a}}$ \\
\hline $100: 0$ & $42.1^{\mathrm{a}}$ & $36.5 \mathrm{~b}$ & $49.1^{\text {a }}$ & $49.4^{\text {a }}$ & $18.4^{\text {a }}$ \\
\hline $\mathrm{CV} \%$ & 47.3 & 57.7 & 50.5 & 62.8 & 100.83 \\
\hline $\mathrm{R}^{2}(\%)$ & 15.1 & 78.3 & 13.09 & 38.12 & 48.2 \\
\hline \multicolumn{6}{|c|}{$P$ content in shoot (mg/plant) } \\
\hline $\mathrm{NH}_{4}^{+}: \mathrm{NO}_{3}^{-}$ & Lettuce* & Tomato & Carrot & Capsicum & Knolkhol \\
\hline $0: 100$ & $9.4^{\mathrm{a}}$ & $12.5^{\mathrm{ab}}$ & $2.9^{\mathrm{a}}$ & $1.2^{\mathrm{a}}$ & $10.2^{\mathrm{a}}$ \\
\hline $25: 75$ & $13.3^{\mathrm{a}}$ & $6.4^{b}$ & $3.9^{a}$ & $3.1^{a}$ & $14.7^{\text {a }}$ \\
\hline $50: 50$ & $8.2^{\mathrm{a}}$ & $24.1^{\mathrm{a}}$ & $0.5^{\mathrm{a}}$ & $0.5^{\mathrm{a}}$ & $13.2^{\mathrm{a}}$ \\
\hline $75: 25$ & $8.3^{\mathrm{a}}$ & $3.9^{b}$ & $5.8^{\mathrm{a}}$ & $3.1^{\mathrm{a}}$ & $8.7^{a}$ \\
\hline $100: 0$ & $5.9^{a}$ & $8.8 \mathrm{ab}$ & $4.7^{\mathrm{a}}$ & $1.6^{\mathrm{a}}$ & $2.5^{\mathrm{b}}$ \\
\hline CV\% & 171.9 & 91.8 & 70.4 & 183.2 & 91.8 \\
\hline $\mathrm{R}^{2}(\%)$ & 17.3 & 55.9 & 43.3 & 50.1 & 31.3 \\
\hline \multicolumn{6}{|c|}{$K$ content in shoot (mg/plant) } \\
\hline $\mathrm{NH}_{4}^{+}: \mathrm{NO}_{3}^{-}$ & Lettuce $^{*}$ & Tomato & Carrot & Capsicum & Knolkhol \\
\hline $0: 100$ & $51.04^{\mathrm{a}}$ & 285.9 a & $157.5^{\text {a }}$ & $60.9 \mathrm{ab}$ & $235.1^{\mathrm{a}}$ \\
\hline $25: 75$ & $86.7^{a}$ & $149.2^{\mathrm{ab}}$ & $160.7^{\mathrm{a}}$ & $30.9^{b}$ & $149.3^{\text {a }}$ \\
\hline $50: 50$ & $80.41^{\mathrm{a}}$ & $171.9 \mathrm{ab}$ & $108.4^{\mathrm{a}}$ & $44.5^{\mathrm{ab}}$ & $146.2^{\mathrm{a}}$ \\
\hline $75: 25$ & $60.8^{a}$ & $119.6^{b}$ & $90.8^{\mathrm{a}}$ & $107.2^{\mathrm{a}}$ & $75.4^{\mathrm{a}}$ \\
\hline 100:0 & $54.4^{\text {a }}$ & $45.3^{\mathrm{b}}$ & $151.0^{\mathrm{a}}$ & $35.4^{b}$ & $11.9^{\mathrm{a}}$ \\
\hline $\mathrm{CV} \%$ & 47.7 & 72.2 & 37.7 & 65.6 & 64.3 \\
\hline $\mathrm{R}^{2}(\%)$ & 36.3 & 60.6 & 52.4 & 93.0 & 74.6 \\
\hline
\end{tabular}

Coefficient of variation (CV\%) and goodness of fit of model $\left(\mathrm{R}^{2}\right)$ are also provided. ${ }^{*}$ Lettuce analysed as whole plant 

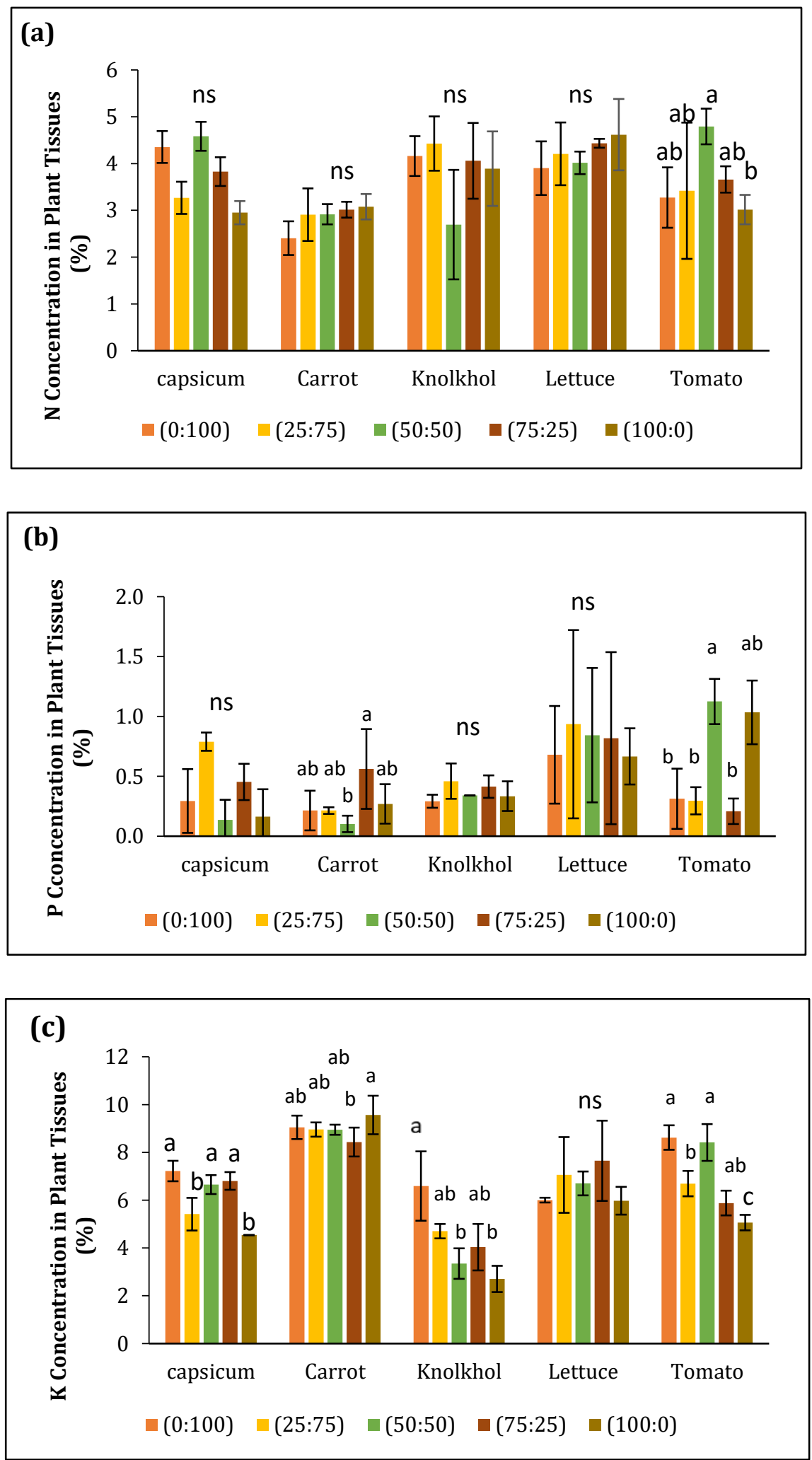

Figure 2: Concentration of (a) N, (b) P and (c) $K$ in shoot tissues of four vegetable crops and whole plant tissues of lettuce at the end of vegetative stage as affected by proportions of ammonium- $\mathrm{N}$ and nitrate- $\mathrm{N}$ in the growth medium. 


\section{CONCLUSIONS}

Six crops used in this study showed different responses towards $\mathrm{N}, \mathrm{P}$ and $\mathrm{K}$ nutrition of plants upon subjecting to different ratios of $\mathrm{NH}_{4}{ }^{+}-\mathrm{N}: \mathrm{NO}_{3}{ }^{-}-$ $\mathrm{N}$ in the growth medium. The performance of carrot, capsicum and lettuce did not change with the form of $\mathrm{N}$ in the growth medium during vegetative growth of the crop. However, tomato, knolkhol and cabbage were sensitive to varying proportions of $\mathrm{NH}_{4}{ }^{+}-\mathrm{N}: \mathrm{NO}_{3}{ }^{-}-\mathrm{N}$ levels in the growth medium. Tomato and knolkhol performed better under higher $\mathrm{NO}_{3}-\mathrm{N}$ levels. Cabbage preferred equal supply of $\mathrm{NH}_{4}{ }^{+}-\mathrm{N}: \mathrm{NO}_{3}-\mathrm{N}$ for dry matter yield.

\section{REFERENCES}

Baruah, T.C and H.P. Barthakur (1997). A text book of soil analysis. Vikas Publishing House (Pvt.) Ltd. New Delhi.

Bybordy, A. (2012). Effect of different ratios of nitrate and ammonium on photosynthesis, and fatty acid composition of canola under saline conditions. International Journal of Agriculture and Crop Sciences. IJACS/2012/4-10/622-626.

Cui, F., Park, S., Mo, K., Lee, W., Lee, H., and Kim, M. (2017). Experimentation and mathematical models for partial nitrification in aerobic granular sludge process. KSCE Journal of Civil Engineering. 21(1), 127-133.

David, S.M., Jeffry, J.F., Peter, G. H. and David, A. Z. (2005). Principles and applications of Soil Microbiology. Pearson Education Inc., Upper Saddle River, New Jersey. 07458.

Devienne-Barret, F., Justes, E., Machet, J. M., and Mary, B. (2000). Integrated control of nitrate uptake by crop growth rate and soil nitrate availability under field conditions. Annals of Botany. 86, 995-1005.

Lathif., M. A and Upali, W.S.P.Y. (2010). Fertilizer recommendations for horticultural crops, Peradeniya, Agriculture Press of Department of Agriculture, Sri Lanka.

Ganmore-Neumann, R. and Kafkafi, U. (1985). The Effect of Root Temperature and Nitrate/Ammonium Ratio on Strawberry Plants. II. Nitrogen Uptake, Mineral Ions, and Carboxylate Concentrations 1. Agronomy Journal. 77(6), 835-840.
It can be concluded that different vegetable crops

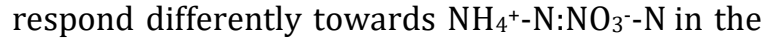
growth medium during vegetative phase. It is important to further investigate how this response during vegetative phase could impact crop yields and the nutritional quality of the yields and the nitrogen use efficiency of the crop.

\section{ACKNOWLEDGMENT}

Financial support received from the National Research Council (NRC grant no. 16-075) and University of Peradeniya Research Grant (URG/2016/10/Ag) is acknowledged.

Heeb, A., B. Lundeg, T. Ericsson and G.P. Savage. (2005). Nitrogen form affects yield and taste of tomatoes. Journal of the Science of Food and Agriculture. 85:1405-1414, DOI: 10.1002 /jsfa.2127

Herrera, J.M., Rubio, G., Häner, L.L., Delgado, J.A., Lucho-Constantino, C.A., Islas-Valdez, S. and Pellet, D. (2016). Emerging and established technologies to increase nitrogen use efficiency of cereals. Agronomy. 6(2), 25.

Hoagland, D.R., and Arnon, D.I. (1950). The waterculture method for growing plants without soil. Circular. California Agricultural Experiment Station, 347 (2 $2^{\text {nd }}$ Edition).

Huang, L., Bell, R.W., Dell, B., and Woodward, J. (2004). Rapid nitric acid digestion of plant material with an open-vessel microwave system. Communications in Soil Science and plant analysis. 35(3-4), 427-440.

Ikeda, $\mathrm{H}$ and Osawa, T. (1981). Nitrate and Ammonium-N absorption by vegetables from nutrient solution containing ammonium nitrate and the resultant change of solution $\mathrm{pH}$. Journal of Japan Society or Horticultural Science, 50(2), 225-230 ISSN 2227-670X @2012 IJACS Journal

Jackson, M.L. (1958). Soil chemical analysis prentice Hall. Inc., Englewood Cliffs, NJ, 498, 183-204

Kafkafi, U. (2009). Root zone temperature and the preferred form of nitrogen to crops, DOI: 10.17660/ActaHortic.2009.807.44

Kemal, Y.O. and Workie, M.A. (2015). Effects of nitrogen inhibitors and slow nitrogen releasing fertilizers on crop yield, nitrogen use efficiency and mitigation of nitrous oxide $\left(\mathrm{N}_{2} \mathrm{O}\right)$ emission. 
Journal of Agriculture and Environmental Sciences. 1(2), 114-125.

Kronzucker, H.J., Siddiqi, M.Y., Glass, A.D. and Kirk, G.J. (1999). Nitrate-ammonium synergism in rice. A subcellular flux analysis. Plant physiology. 119(3), 1041-1046.

Marti, H.R. and Mills, H.A. (1991). Nutrient uptake and yield of sweet pepper as affected by stage of development and $\mathrm{N}$ form. Journal of plant nutrition. 14(11), 1165-1175

Nasraoui-Hajaji, A., Chaffei-Haouari, C., Ghorbel, M.H. and Gouia, H. (2011). Growth and nitrate assimilation in tomato (Solanum lycopersicon) grown with different nitrogen source and treated with cadmium. Acta Botanica Gallica, 158(1), 3-11.

Olsen, S.R. and Sommers, L.E. (1982). Phosphorus. pp. 403-430. In: A. L. Page, et al. (Eds.) Methods of soil analysis: Part 2. Chemical and microbiological properties. Agronomy Mongraphs, 9. Second Edition. ASA and Soil Science Society of America, Madison, WI.

Omari, R.E.L and Nhiri, M. (2015). Effect of High levels of ammonium or nitration on growth and nitrogen metabolism in roots and leaves of Sorghum (Sorghum Sudan grass) plants, America-Eurasian Journal of Agriculture and Environment Science, 15(9): 1860-1867. ISSN 1818-6769, (C) IDOSI Publications, 2015, DOI: 10.5829/idosi.aejaes.2015.15.9.95303

Palaniswamy, U.R., Bible, B.B. and McAvoy, R.J. (2002). Effect of nitrate: Ammonium nitrogen ratio on oxalate levels of purslane. p. 453-455.
In: J. Janick and A. Whipkey (Eds.), Trends in new crops and new uses. ASHS Press,

Rodgers, G.A. (1986). Nitrification inhibitors in agriculture. Journal of Environmental Science and Health Part A. 21(7), 701-722.

Scaife, A., Saraiva Ferreira, M.E. and Turner, M.K. (1986). Effect of nitrogen form on the growth and nitrate concentration of lettuce. Plant and Soil. 94(1), 1-3.

Serna, M.D., Borras, R. and Legaz, F. (1992). The influence of nitrogen concentration and ammonium/nitrate ratio on $\mathrm{N}$-uptake, mineral composition and yield of citrus. Plant and Soil. $147,13-23$

Slangen, J.H.G. and Kerkhoff, P. (1984). Nitrification inhibitors in agriculture and horticulture: a literature review. Fertilizer Research. 5(1), 176.

Sutton, S. (2011). Measurement of microbial cells by optical density. Journal of Validation Technology. 17(1), 46-49.

Tian, X., Li, S., Wang, Z., Yin, X. and Chen, S. (2003). Response of lettuce to different nitrogen forms. Ying Yong Sheng Tai Xue Bao. 14(3), 377-381.

Upadhya, R.K., Patra, D.D. and Tewari, S.K. (2011). Natural nitrification inhibitors for higher nitrogen use efficiency, crop yield, and for curtailing global warming. Journal of Tropical Agriculture. 49, 19-24.

Zhang, F., Niu, J., Zhang, W., Chen, X., Li, C., Yuan, L. and Xie, J. (2010). Potassium nutrition of crops under varied regimes of nitrogen supply. Plant and soil. 335(1-2), 21-34. 